\title{
DINAMIKA OVARIUM PADA KUDA HASIL PERSILANGAN PEJANTAN THOROUGHBRED DENGAN INDUK LOKAL INDONESIA
}

\section{OVARIAN DYNAMICS IN THE THOROUGHBRED-INDONESIAN LOCAL CROSSBRED MARES}

\author{
Muhammad Danang Eko Yulianto ${ }^{1 *}$, Bambang Purwantara ${ }^{2}$, dan Amrozi $^{2}$ \\ ${ }^{1}$ Departemen Produksi Ternak, Fakultas Peternakan, Universitas Gadjah Mada, Yogyakarta, 55281 \\ ${ }^{2}$ Departemen Klinik Reproduksi dan Patologi, Fakultas Kedokteran Hewan, Institut Pertanian Bogor, \\ Bogor, 16680
}

Submitted: 28 April 2016, Accepted: 23 September 2016

\section{INTISARI}

Penelitian dilakukan terhadap tiga ekor kuda hasil persilangan antara pejantan Thoroughbred dengan induk lokal, dengan kandungan genetik lokal antara 6,25\% sampai dengan 12,5\% dengan kisaran umur 12-20 tahun. Penelitian dimulai dengan sinkronisasi estrus yang dilakukan dengan penyuntikan hormon PGF $_{2 \alpha}$ dosis tunggal $10 \mathrm{mg}$ i.m pada fase luteal, diikuti dengan penyuntikan $1.500 \mathrm{IU}$ hCG pada saat folikel dominan telah mencapai diameter $\geq 30 \mathrm{~mm}$. Pemeriksaan dengan ultrasonografi dilakukan secara rutin pada waktu yang sama. Dari pengamatan terhadap sinkronisasi estrus dan induksi ovulasi didapatkan hasil bahwa interval awal perlakuan $\mathrm{PGF}_{2 a}$ hingga onset estrus adalah 1,33 $\pm 0,58$ hari, dengan lama estrus 4,00 $\pm 1,00$ hari, interval mencapai ovulasi dari awal perlakuan PGF $2 \alpha$ adalah $5,33 \pm 1,15$ hari, sedangkan dari awal perlakuan hCG adalah 66,67 $\pm 10,07$ jam. Diamater maksimal folikel terbesar adalah $4,50 \pm 0,52 \mathrm{~cm}$ yang dicapai sehari sebelum terjadinya ovulasi. Secara umum dapat dilihat bahwa rerata panjang siklus estrus kuda hasil persilangan pejantan Thoroughbred dengan induk lokal Indonesia yang telah berumur 12-20 tahun adalah 25,4 $\pm 3,38$ hari dengan 2 sampai 3 gelombang folikel dan lama estrus $6,8 \pm 1,92$ hari. Rerata diameter folikel terbesar maksimum sebelum ovulasi adalah $4,2 \pm 1,24 \mathrm{~cm}$ dengan kisaran 3,0 sampai dengan $5,8 \mathrm{~cm}$. Hasil pengamatan terhadap tingkah laku estrus menunjukkan bahwa saat-saat menjelang ovulasi akan ditandai dengan pencapaian skor maksimal pada nilai 3, yang dicirikan dengan lebih menunjukkan ketertarikan terhadap pejantan, mengangkat ekor, winked vulva, squatting dan urinasi dan pada nilai 4 yang dicirikan dengan ketertarikan yang kuat terhadap pejantan, menyodorkan pantat pada jantan, mengangkat ekor dan winked vulva serta urinasi yang berkelanjutan.

(Kata kunci: Dinamika ovarium, Estrus, Kuda betina, Siklus, Ultrasonografi)

\section{ABSTRACT}

The development of horse breeding industry in Indonesia was commenced through horse racing events held all over the country. It were accelerated by the development of Thoroughbred-Indonesian local Crossbred horses. There are many broodmares injured during their racing time and retired from the racetracks. They may still has a reproductive vigor to continue on producing offsprings. Very little information has been reported on the monitoring the reproductive capacity of the mares. The objective of this study was to explore ultrasonography imaging of the ovarian dynamics, correlated with the estrus behavior of the Thoroughbred-Indonesian local crossbred mares. Three Thoroughbred-Indonesian local crossbred mares with $6.25-12.5 \%$ of local genetics aged $12-20$ years old were used in this study. Estrus and ovulation were synchronized by $10 \mathrm{mg}$ PGF $2 a$ i.m. at luteal phase and 1,500 IU hCG i.m. injection when the dominant follicle reach $\geq 30 \mathrm{~mm}$ in diameter. Ultrasonography examination was done every morning at approximately at the same time. Estrus behavior was observed by using teaser stallions following a standard method. Results of the experiment indicated that onset of the estrus was reached $1.33 \pm 0.58$ days after the $h C G$ injection, with the average duration of $4.00 \pm 1.00$ days. The ovulations were done at 5.33 \pm 1.15 days after PGF $2 a$ treatment and $66.67 \pm 10.07$ hours after hCG treatment. Maximum follicle diameter was identified to reach $4.50 \pm 0.52 \mathrm{~cm}$ at one day before ovulation. The mares performed 25.4 \pm 3.38 days length of estrus cycle with 2-3 follicular waves. It had been identified that the estrus duration was $6.8 \pm 1.92$ days in mares with the age of $12-20$ years. The average of maximum diameter of

\footnotetext{
* Korespondensi (corresponding author):

Telp. +62 8156733547

E-mail: danangyulianto@ugm.ac.id
} 
the largest follicle before ovulation was $4.2 \pm 1.24 \mathrm{~cm}$. In conclusion, to improve the efficiency of breeding, several information are needed i.e. the optimal time of ovulation, relevan parameters related to follicular development.

(Key word: Cycle, Estrus, Mares, Ovarian dynamics, Ultrasonography)

\section{Pendahuluan}

Di Indonesia, industri ternak kuda sudah mulai berkembang dengan munculnya kuda persilangan Thoroughbred dengan lokal Indonesia, yang digunakan sebagai kuda pacu. Sementara itu, masa pakainya sebagai kuda pacu terbatas, sehingga banyak kuda betina yang dijadikan induk setelah pensiun dari arena pacuan kuda. Saat ini persilangan antara kuda lokal Indonesia dengan kuda pejantan Thoroughbred dibatasi sampai terbentuknya keturunan ke-tiga (G3) dan ke-empat (G4), setelah itu dilakukan perkawinan antar sesama, yaitu antara G3 dengan G3, G3 dengan G4, dan G4 dengan G4 yang akan menghasilkan Kuda Pacu Indonesia (KPI) (PP. PORDASI, 2000 cit. Berliana, 2007). Siklus reproduksi terkait dengan berbagai fenomena; pubertas dan kematangan seksual, musim kawin, siklus estrus, aktivitas seksual setelah beranak, dan penuaan atau umur (Hafez 2000), sementara itu Donadeu dan Ginther (2002) melaporkan bahwa gelombang folikel berkembang pada waktu pertengahan siklus estrus, dan pada umumnya satu folikel akan diovulasikan pada akhir estrus. Interval interovulatory pada kuda terdiri atas berbagai kombinasi gelombang folikel minor, di mana folikel terbesar tidak menjadi dominan, serta gelombang mayor, folikel yang terbesar menjadi dominan. Interval interovulatory dimulai pada saat ovulasi yang diawali estrus dan diakhiri pada saat ovulasi estrus berikutnya. Rerata panjang interval interovulatory adalah 21 atau 22 hari pada kuda, dan 24 hari pada pony (Ginther, 1992). Setelah kemunculan gelombang folikuler yang akan disertai ovulasi, folikel akan tumbuh dengan laju pertumbuhan yang normal, sampai dengan awal deviasi, dimana pada saat deviasi, pertumbuhan folikel dominan berlanjut, sedangkan folikel subordinat akan terregresi. Deviasi dimulai pada saat calon folikel dominan mencapai ukuran 22,5 mm (Ginther et al., 2004).

Di Indonesia, pemanfaatan teknik ultrasonografi (USG) dalam pemeriksaan reproduksi kuda sudah mulai banyak digunakan oleh para peternak pada beberapa tahun terakhir ini yang bertujuan untuk meningkatkan efisiensi reproduksi serta mendapatkan hasil yang optimal. Penelitian ini dilakukan dengan tujuan untuk mengetahui gambaran ultrasonografi dinamika ovari, terkait dengan tingkah laku estrus dalam satu siklus estrus kuda hasil persilangan pejantan Thoroughbred dengan induk lokal Indonesia. Hasil penelitian ini diharapkan dapat memberikan petunjuk untuk penentuan waktu perkawinan yang optimal berdasarkan gambaran ultrasonografi dinamika ovari dan tingkah laku estrusnya.

\section{Materi dan Metode}

\section{Tempat dan hewan penelitian}

Penelitian dilaksanakan di Unit Rehabilitasi Reproduksi Bagian Kebidanan dan Kemajiran Departemen Klinik, Reproduksi, dan Patologi, Fakultas Kedokteran Hewan, Institut Pertanian Bogor. Penelitian dilakukan terhadap tiga ekor kuda hasil persilangan antara pejantan Thoroughbred dengan induk lokal, dengan kandungan genetik lokal antara 6,25\% sampai dengan $12,5 \%$ dengan kisaran umur 12-20 tahun yang dipelihara secara intensif. Kuda-kuda tersebut diberi pakan berupa hijauan rumput segar dan konsentrat dengan kadar protein $12 \%$.

\section{Alat dan bahan}

Alat yang akan digunakan dalam penelitian ini terdiri atas; USG (ALOKA SSD500, Aloka Co.Ltd, Japan), linear probe 5 MHz (ALOKA UST-588U-5, Aloka Co. Ltd. Japan), printer (SONY, UP-895 MD, Video Graphic Printer, Japan), syringe (One Med, PT. Jaya Mas Medica Industri), dan plastic gloves (Europlex ${ }^{\circledR}$, Divasa Farmativa, S.A.). Bahan yang akan digunakan dalam penelitian ini terdiri atas; Gel lubrikasi, PGF2a (Dinoprost, Noroprost 0,5\% W/V, Norbrook Laboratories Limited, Newry), hCG (Chorulon, Intervet, Cambridge), alkohol $70 \%$, dan kapas. 


\section{Prosedur pelaksanaan penelitian}

Sinkronisasi estrus dan ovulasi. Penelitian dimulai dengan sinkronisasi estrus yang dilakukan dengan penyuntikan hormon $\mathrm{PGF}_{2 \alpha}$ (Dinoprost, Noroprost 0,5\% W/V, Norbrook Laboratories Limited, Newry) single-dose pada fase luteal, diikuti dengan penyuntikan hCG (Chorulon, Intervet, Cambridge) single-dose 1.500 IU pada saat folikel dominan mencapai diameter $30 \mathrm{~mm}$.

Tingkah laku estrus. Pengamatan tingkah laku estrus dilakukan dua kali, yang pertama dilakukan mulai dari satu hari setelah pemberian $\mathrm{PGF}_{2 \alpha}$ sampai dengan ovulasi I. Pengamatan yang kedua dilakukan mulai hari ke-17 sampai dengan ovulasi II dengan teknik teasing, yaitu dengan memancing kuda betina pada kuda jantan teaser. Pengamatan dilakukan dengan sistem scoring menurut Coleman dan Powell (2004) seperti pada Tabel 1.

\section{Ultrasonografi}

Pemeriksaan dengan USG dilakukan setiap hari pada waktu yang sama, dimulai sesaat setelah sinkronisasi estrus, dan setiap empat jam sekali sesaat setelah dilakukan penyuntikan hCG sampai dengan terjadinya ovulasi untuk mengamati dinamika ovari yang terjadi, meliputi diameter Corpus Luteum (CL) dan jumlah beserta ukuran folikel yang kemudian akan diklasifikasikan menjadi folikel kelas I berdiameter $<2 \mathrm{~cm}$, kelas II berdiameter $2-4 \mathrm{~cm}$, serta kelas III berdiameter $>4 \mathrm{~cm}$. Diameter masing-masing folikel preovulasi diukur dengan nilai rerata dimensi tersempit dan terlebarnya (Shirazi, 2004). Kondisi organ reproduksi yang meliputi cervix, corpus dan cornua uteri juga diamati dengan teknik USG untuk mengetahui diameter serta keberadaan lendir birahinya.

Teknik USG yang dilakukan adalah secara per rektal. Linear probe dimasukkan ke dalam rectum untuk mengeksplorasi organ reproduksi, dimulai dari cervix, corpus, dan cornua uteri, sampai dengan ovarium kanan dan kiri dilakukan dengan seksama dan teliti. Caliper pada monitor USG digunakan untuk mengukur diameter folikel dan CL. Hasil USG dicetak dengan printer untuk menghasilkan sonogram, serta dilakukan pemetaan posisi folikel dan CL pada ovarium.

\section{Analisa data}

Data yang terkumpul akan disajikan secara deskriptif kuantitatif dengan perhitungan rerata dan standar deviasi. Analisa akan menggunakan software MS Office Excel 2007 (Steel dan Torrie, 1999).

\section{Hasil dan Pembahasan}

\section{Sinkronisasi estrus dan ovulasi}

Berdasarkan hasil penelitian, untuk sinkronisasi estrus dan ovulasi yang dilakukan dengan pemberian $\mathrm{PGF}_{2 \alpha} 2 \mathrm{ml}$ i.m dan hCG 1.500 IU i.m didapatkan hasil seperti tertera pada Tabel 2. Rerata diameter folikel terbesar pada saat awal treatmen $\mathrm{PGF}_{2 \alpha}$ adalah sebesar 2,63 $\pm 0,06 \mathrm{~cm}$ dan pada awal treatmen hCG adalah sebesar $3,27 \pm 0,12 \mathrm{~cm}$. Untuk rerata diameter folikel terbesar maksimal dicapai pada satu hari sebelum ovulasi, yaitu sebesar 4,50 $\pm 0,52$ cm. Bergfelt et al. (2007) melaporkan bahwa dalam penelitian yang telah dilakukannya, rerata diameter folikel terbesar pada saat awal treatmen $\mathrm{PGF}_{2 \alpha}$ sebesar 2,27 $\pm 0,19 \mathrm{~cm}$ dengan kisaran 1 sampai $4 \mathrm{~cm}$, sedangkan pada awal treatmen hCG sebesar $3,15 \pm 0,15$ $\mathrm{cm}$ dengan kisaran 1,9 sampai $4,5 \mathrm{~cm}$. Rerata diameter folikel terbesar maksimal yang dicapai satu hari sebelum ovulasi sebesar 3,65 $\pm 0,1 \mathrm{~cm}$ dengan kisaran 2,8 sampai $4,5 \mathrm{~cm}$.

Tabel 1. Sistem scoring pengamatan tingkah laku estrus pada kuda (estrus behavior scoring system in mares)

\begin{tabular}{cl}
\hline \hline Skor (score) & \multicolumn{1}{c}{ Tanda-tanda yang dapat diamati pada kuda betina (heat symptom in mares) } \\
\hline 0 & $\begin{array}{l}\text { Tidak menunjukkan tanda-tanda menerima jantan, bahkan agresif - menyerang, } \\
\text { menendang, meringkik (agresive to the stallion, even attacking or kicking) }\end{array}$ \\
1 & $\begin{array}{l}\text { Tidak menolak terhadap pejantan (stay when the stallion is approaching) } \\
\text { Sedikit ada ketertarikan, kadang mendekati pejantan, menunjukkan winked vulva, dan } \\
\text { mengangkat ekor (begin to approach the stallion, winked vulva, tail raising) }\end{array}$ \\
3 & $\begin{array}{l}\text { Lebih menunjukkan ketertarikan, mengangkat ekor, squatting, dan urinasi (more attracted } \\
\text { to stallion, tail raising, squatting, urinating) } \\
\text { Ketertarikan yang kuat, menyodorkan pantat pada jantan, dan winked vulva, serta urinasi } \\
\text { yang berkelanjutan (strongly attracted to stallion, winked vulva, and continuous urinating) }\end{array}$ \\
\hline
\end{tabular}


Tabel 2. Data hasil pengamatan sinkronisasi estrus dan ovulasi (data of estrus syncronization and ovulation)

\begin{tabular}{|c|c|}
\hline Parameter & Rerata \pm SD $($ mean $\pm S D)$ \\
\hline \multicolumn{2}{|l|}{ Diamater folikel terbesar $(\mathrm{cm})$ (largest follicle diameter $(\mathrm{cm})$ ) } \\
\hline Awal treatmen $\mathrm{PGF}_{2 \alpha}$ (early $P G F_{2 \alpha}$ treatment) & $2,63 \pm 0,06$ \\
\hline Awal treatmen hCG (early hCG treatment) & $3,27 \pm 0,12$ \\
\hline Maksimal (maximum) & $4,50 \pm 0,52$ \\
\hline Hari sebelum ovulasi (day before ovulation) & $4,50 \pm 0,52$ \\
\hline \multicolumn{2}{|l|}{ Diameter CL $(\mathrm{cm})(C L$ diameter $(\mathrm{cm}))$} \\
\hline Awal treatmen $P G F_{2 \alpha}$ (early $P G F_{2 \alpha}$ treatment) & $2,17 \pm 0,15$ \\
\hline Awal treatmen hCG (early hCG treatment) & $1,77 \pm 0,45$ \\
\hline Hari sebelum ovulasi (day before ovulation) & $0,83 \pm 0,32$ \\
\hline \multicolumn{2}{|l|}{ Estrus (hari) (estrus (days)) } \\
\hline Interval awal treatmen PGF $_{2 \alpha}$ hingga onset estrus (early & \\
\hline$P G F_{2 \alpha}$ treatment to estrus onset interval) & $1,33 \pm 0,58$ \\
\hline Durasi estrus (estrus duration) & $4,00 \pm 1,00$ \\
\hline \multicolumn{2}{|l|}{ Interval mencapai ovulasi (interval to ovulation occured) } \\
\hline Awal treatmen PGF2 $\alpha$ (hari) (early PGF $2 a$ treatment (days)) & $5,33 \pm 1,15$ \\
\hline Awal treatmen hCG (jam) (early hCG treatment (hours)) & $66,67 \pm 10,07$ \\
\hline
\end{tabular}

Rerata diameter CL pada saat awal treatmen $\mathrm{PGF}_{2 \alpha}$ didapatkan sebesar $2,17 \pm 0,15 \mathrm{~cm}$, sedangkan pada saat awal tretamen hCG sebesar 1,77 $\pm 0,45 \mathrm{~cm}$, dan satu hari sebelum ovulasi sebesar $0,83 \pm 0,32$ $\mathrm{cm}$. Rerata Interval awal treatmen $P G F_{2 \alpha}$ hingga onset estrus sepanjang 1,33 $\pm 0,58$ hari, sedangkan rerata durasi estrus sepanjang 4,00 $\pm 1,00$ hari. Interval mencapai ovulasi dari awal treatmen $\mathrm{PGF}_{2 \alpha}$ selama $5,33 \pm 1,15$ hari, sedangkan dari awal treatmen hCG $6,67 \pm 10,07$ jam. Penelitian tersebut kurang sesuai dengan hasil penelitian yang dilakukan oleh Samper (2008), yang telah dilaporkan bahwa dalam rerata, onset estrus dan ovulasi akan terjadi dalam kurun waktu 3-4 hari dan 8-10 hari setelah treatmen PGF2a. Namun demikian, selanjutnya Samper (2008) menambahkan bahwa kisaran antara awal treatmen PGF $2 \alpha$ sampai dengan onset estrus dan tercapainya ovulasi dapat berkisar antara 48 jam sampai dengan 12 hari, tergantung dari diameter folikel yang akan ovulasi. Gastal et al. (2006) juga melaporkan bahwa dengan treatmen 1.500 IU hCG akan didapatkan interval mencapai ovulasi sepanjang 44,0 $\pm 1,0$ jam.

Jika pada saat treatmen $\mathrm{PGF}_{2 \alpha}$ terdapat folikel yang tumbuh dan berukuran besar, kemungkinan akan terjadi ovulasi dalam 72 jam setelah treatmen, tanpa adanya tanda estrus yang nampak jelas. Sebaliknya, jika folikel telah mencapai diameter maksimalnya selama luteal fase yang didominasi oleh progesteron, maka folikel ini akan regresi, dan akan terjadi perekrutan folikel-folikel yang baru, maka estrus dan ovulasi akan tertunda (Samper et al., 1993).

\section{Dinamika perkembangan folikel dan corpus luteum}

Berdasarkan hasil pengamatan pada saat penelitian, ditunjukkan bahwa pada kuda A didapatkan tiga siklus estrus dengan masing-masing panjang siklus 28, 19, dan 25 hari, sehingga didapatkan rerata panjang siklus untuk kuda A sepanjang $24 \pm 4,58$ hari. Dinamika perkembangan folikel pada siklus I sepanjang 28 hari, diawali dengan diameter folikel terbesar (1 $1^{\text {st }}$ DF) sebesar $2,1 \mathrm{~cm}$, sedangkan $1^{\text {st }} \mathrm{SF}$ sebesar 1,5 , dan $\mathrm{CL}$ sebesar $3,3 \mathrm{~cm} .1^{\text {st }}$ DF dan $1^{\text {st }} \mathrm{SF}$ mengalami regresi pada hari ke-8 dengan diameter masing-masing diameter 1,6 dan $1,2 \mathrm{~cm}$, dilanjutkan dengan pertumbuhan $2^{\text {nd }}$ DF dan $2^{\text {nd }}$ SF dengan diameter masing-masing 2,0 dan $1,3 \mathrm{~cm}$ sampai dengan regresi pada hari ke-19 dengan diameter masing-masing 1,9 dan $1,4 \mathrm{~cm}$, kemudian muncul gelombang folikel ke-3 yang ditandai dengan pertumbuhan $3^{\text {rd }}$ DF dan $3^{\text {rd }}$ SF berdiameter masing-masing 2,6 dan $1,8 \mathrm{~cm}$ dan berlanjut hingga terjadi ovulasi pada hari ke-28 dengan diameter folikel dominan maksimal sebesar 3,2 cm. Regresi CL terlihat drastis pada hari ke-25, dengan diameter $1,6 \mathrm{~cm}$, setelah hari ke-24 sebesar $2,0 \mathrm{~cm}$, hingga mencapai ukuran $1,4 \mathrm{~cm}$ pada saat terjadinya ovulasi.

Sementara itu, pada siklus ke-Il dari kuda $A$, didapatkan hasil pengamatan bahwa panjang siklus adalah 19 hari, diawali dengan diameter folikel terbesar (1 ${ }^{\text {st }}$ DF) sebesar $2,0 \mathrm{~cm}$, sedangkan $1^{\text {st }} \mathrm{SF}$ sebesar 
1,8 cm, dan CL sebesar 2,4 cm. $1^{\text {st }} \mathrm{DF}$ dan $1^{\text {st }}$ SF mengalami regresi pada hari ke-4 dengan diameter masing-masing 2,0 dan 1,8 $\mathrm{cm}$, dilanjutkan dengan pertumbuhan $2^{\text {nd }} \mathrm{DF}$ dan $2^{\text {nd }}$ SF dengan diameter masing-masing $1,5 \mathrm{~cm}$ sampai dengan regresi pada hari ke12 dengan diameter masing-masing 2,4 dan $1,4 \mathrm{~cm}$. gelombang folikel ke-3 muncul pada hari ke-12, bersamaan dengan pertumbuhan $3^{\text {rd }}$ DF dan $3^{\text {rd }}$ SF berdiamater masingmasing 2,4 dan $1,5 \mathrm{~cm}$ dan berlanjut sampai dengan terjadi ovulasi pada hari ke-19 dengan diameter folikel dominan maksimal sebesar $5,2 \mathrm{~cm}$. diameter $\mathrm{CL}$ pada saat terjadinya ovulasi sebesar $0,7 \mathrm{~cm}$.

Siklus ke-III dari kuda A sepanjang 25 hari dengan tiga gelombang folikel. Diawali dengan pertumbuhan $1^{\text {st }}$ DF dan $1^{\text {st }}$ SF yang berdiameter masing-masing sebesar 1,6 dan $1,2 \mathrm{~cm}$, serta CL berdiameter $3,4 \mathrm{~cm}$. $1^{\text {st }} \mathrm{DF}$ dan $1^{\text {st }}$ SF mengalami regresi pada hari ke- 6 dengan diameter masing-masing 1,9 dan 1,7 $\mathrm{cm}$, dilanjutkan dengan pertumbuhan $2^{\text {nd }}$ DF dan $2^{\text {nd }}$ SF dengan diameter masing-masing
1,4 dan 1,3 cm sampai dengan regresi pada hari ke-15 dengan diameter masing-masing 1,6 dan 0,9 cm. Gelombang folikel ke-3 muncul pada hari ke-16, bersamaan dengan pertumbuhan $3^{\text {rd }}$ DF dan $3^{\text {rd }}$ SF berdiamater masing-masing 2,8 dan $1,4 \mathrm{~cm}$ dan berlanjut sampai dengan terjadi ovulasi pada hari ke25 dengan diameter folikel dominan maksimal sebesar 3,0 cm. Diameter $\mathrm{CL}$ pada saat terjadinya ovulasi sebesar $0,8 \mathrm{~cm}$.

Berdasarkan hasil pengamatan pada saat penelitian menunjukkan bahwa pada kuda B didapatkan satu siklus estrus dengan panjang siklus 28 hari dengan dua gelombang folikel. Dinamika perkembangan folikel pada kuda B diawali dengan pertumbuhan folikel terbesar (1 ${ }^{\text {st }}$ DF) berdiameter $1,9 \mathrm{~cm}$, sedangkan $1^{\text {st }} \mathrm{SF}$ sebesar $1,5 \mathrm{~cm}$, dan CL sebesar $3,5 \mathrm{~cm} .1^{\text {st }}$ DF dan $1^{\text {st }}$ SF mengalami regresi pada hari ke-5 dengan diameter masing-masing diameter 1,0 dan $0,9 \mathrm{~cm}$, dilanjutkan dengan pertumbuhan $2^{\text {nd }}$ DF dan $2^{\text {nd }}$ SF dengan diameter masing-masing $1,5 \mathrm{~cm}$ dan
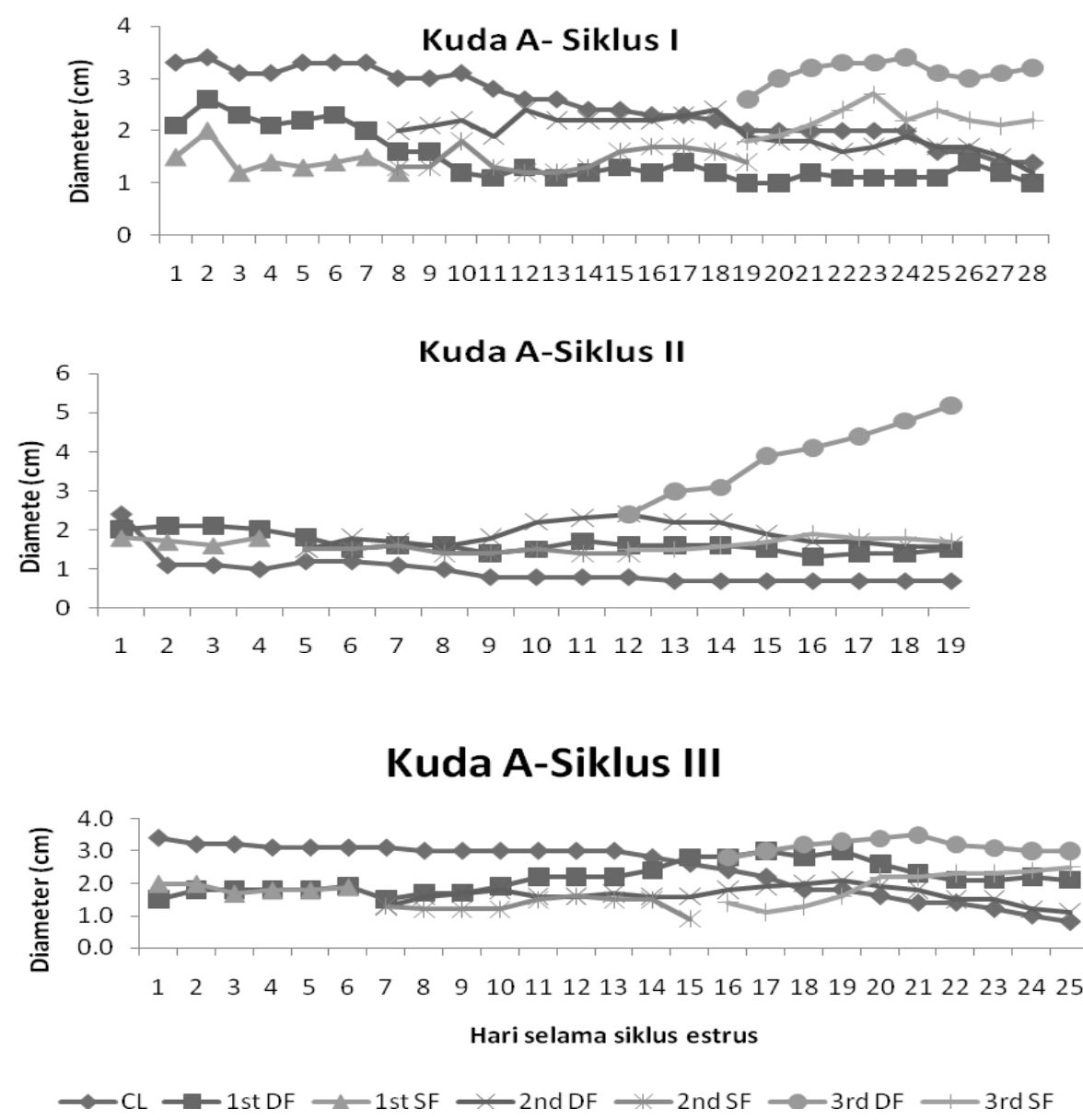

Gambar 1. Grafik dinamika ovari pada kuda A (graphic of ovari dynamics on mares A). 
berlanjut hingga terjadi ovulasi pada hari ke28 dengan diameter folikel dominan maksimal sebesar 3,8 cm. Diameter CL pada saat terjadinya ovulasi sebesar $1,0 \mathrm{~cm}$.

Kuda C mempunyai siklus sepanjang 27 hari dengan dua gelombang folikel. Diawali dengan pertumbuhan $1^{\text {st }}$ DF dan $1^{\text {st }}$ SF yang berdiameter masing-masing sebesar 2,8 dan 2,1 cm, serta $\mathrm{CL}$ berdiameter $2,5 \mathrm{~cm}$. $1^{\text {st }} \mathrm{DF}$ dan $1^{\text {st }} \mathrm{SF}$ mengalami deviasi pada hari ke-10 dengan diameter masing-masing 1,9 dan $1,2 \mathrm{~cm}$, dilanjutkan dengan pertumbuhan $2^{\text {nd }}$ DF dan $2^{\text {nd }}$ SF dengan diameter masing-masing 2,8 dan $1,8 \mathrm{~cm}$ dan berlanjut sampai dengan terjadi ovulasi pada hari ke-27 dengan diameter folikel dominan maksimal sebesar $5,8 \mathrm{~cm}$. Diameter CL pada saat terjadinya ovulasi sebesar $0,5 \mathrm{~cm}$.

Berdasarkan data-data tersebut, dapat dilihat bahwa rerata panjang siklus estrus adalah $25,4 \pm 3,38$ hari dengan dua sampai tiga gelombang folikel. Rerata diameter folikel terbesar maksimum sebelum ovulasi adalah 4,2 $\pm 1,24 \mathrm{~cm}$ dengan kisaran 3,0 sampai dengan 5,8 cm. Donadeu dan Ginther (2002) melaporkan bahwa gelombang folikel berkembang pada waktu pertengahan siklus estrus, dan pada umumnya satu folikel akan diovulasikan pada akhir estrus. Interval interovulatory pada kuda terdiri atas berbagai kombinasi gelombang folikel minor, di mana folikel terbesar tidak menjadi dominan, serta gelombang mayor, di mana folikel yang terbesar menjadi dominan. Interval interovulatory dimulai pada saat ovulasi yang diawali estrus dan diakhiri pada saat ovulasi estrus berikutnya. Rerata panjang interval interovulatory adalah 21 atau 22 hari pada kuda, dan 24 hari pada pony (Ginther, 1992).

\section{Tingkah laku estrus}

Hasil pengamatan terhadap tingkah laku estrus pada saat penelitian menunjukkan bahwa pada seiring dengan waktu terjadinya estrus, maka skor tingkah laku estrus juga semakin meningkat, dan bersamaan dengan tercapainya ovulasi, skor juga akan mencapai maksimal pada nilai 3 , yang dicirikan dengan lebih menunjukkan ketertarikan, mengangkat ekor, squatting, serta urinasi, dan pada nilai 4 yang dicirikan dengan ketertarikan yang kuat, menyodorkan pantat pada jantan, dan winked vulva, serta urinasi yang berkelanjutan.

Tingkah laku individu selama estrus bervariasi antar individu kuda, tetapi cenderung sama antar siklus. Tanda-tanda estrus yang dapat dilihat, di antaranya adalah penerimaan terhadap pejantan, ekor terangkat, sering urinasi, vulva mengedip (winking), dan cara berdiri cenderung jongkok (squatting) (Coleman dan Powell, 2004). Sementara itu Waring (2003) menyatakan bahwa pada saat estrus, kuda

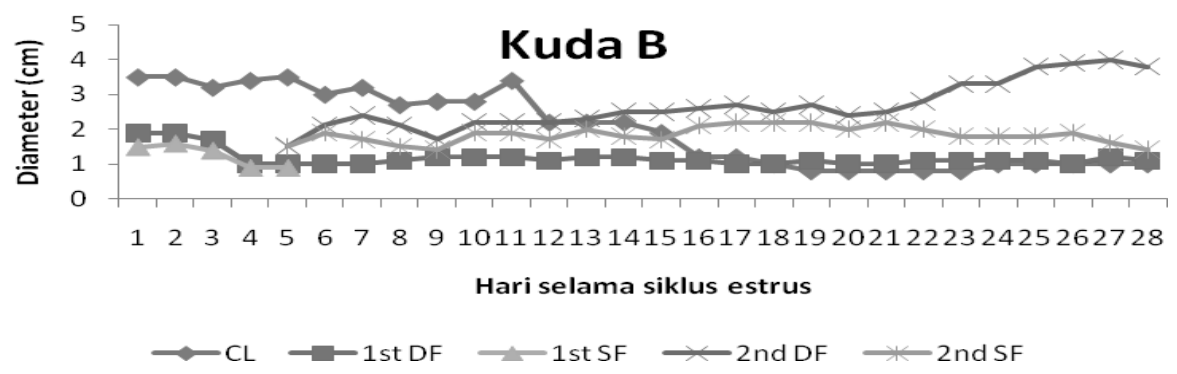

Gambar 2. Grafik dinamika ovari pada kuda B (graphic of ovari dynamics on mares $B$ ).

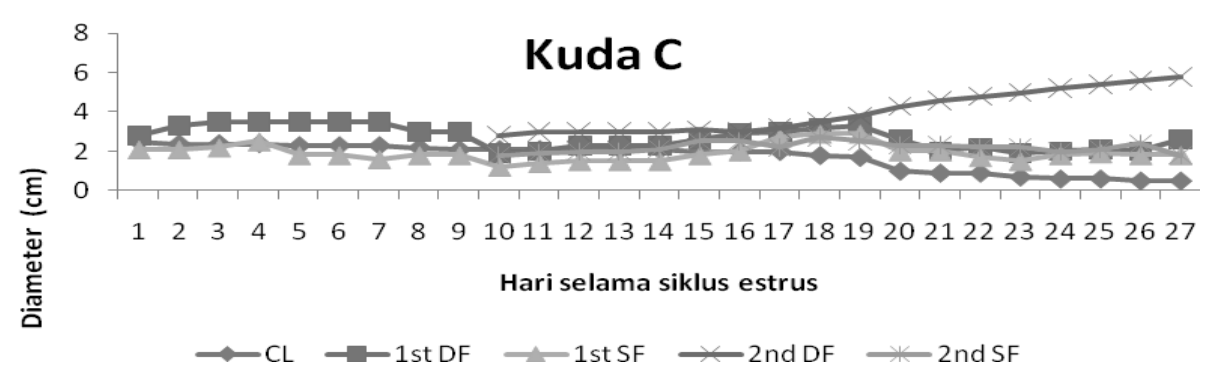

Gambar 3. Grafik dinamika ovari pada kuda C (graphic of ovari dynamics on mares C). 


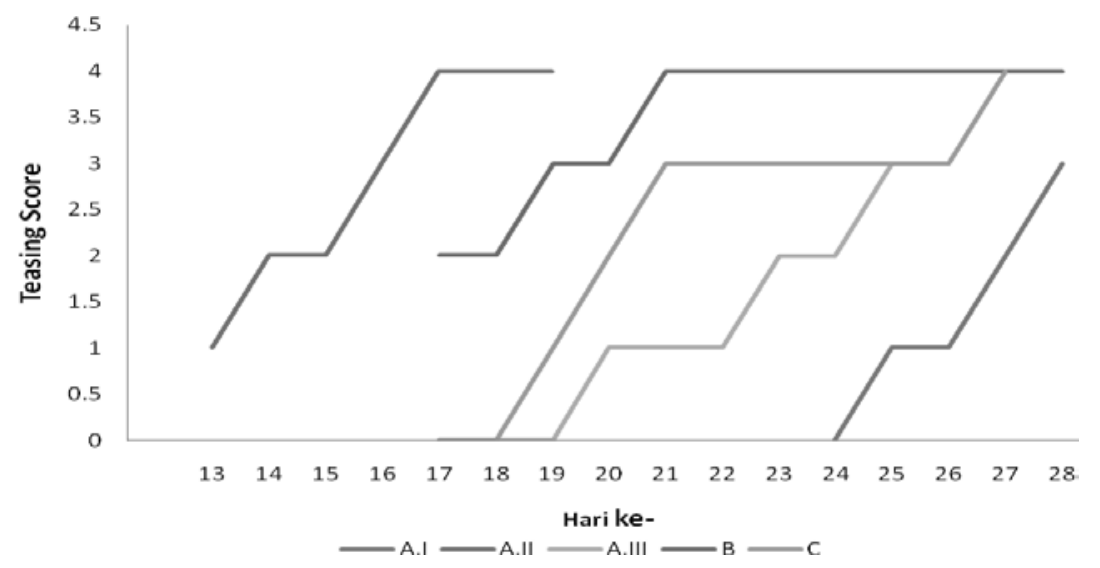

Gambar 4. Grafik hasil skoring tingkah laku estrus (estrus behavior scoring).

betina akan menjadi relatif lebih jinak dengan kehadiran pejantan, dan akan membiarkan pejantan untuk mengendus, menyundul, dan menggigitnya, terkadang kuda betina akan meringkik. Hafez (2000) menambahkan bahwa selama dalam periode estrus, vulva akan membengkak, bagian bibirnya akan mengendur, dan akan mudah dibuka ketika akan diperiksa. Vulva berwarna merah tua, basah, mengkilap, dan diselaputi lendir yang bening.

\section{Kesimpulan}

Hasil pengamatan terhadap sinkronisasi estrus dan ovulasi didapatkan hasil bahwa interval awal treatmen $P F_{2 \alpha}$ hingga onset estrus adalah 1,33 $\pm 0,58$ hari, dengan durasi estrus 4,00 $\pm 1,00$ hari, interval mencapai ovulasi dari awal treatmen PGF2 $\alpha$ adalah 5,33 $\pm 1,15$ hari, sedangkan dari awal treatmen hCG adalah 66,67 $\pm 10,07$ jam. Diamater maksimal folikel terbesar adalah $4,50 \pm 0,52 \mathrm{~cm}$ yang dicapai sehari sebelum terjadinya ovulasi. Secara umum dapat dilihat bahwa rerata panjang siklus estrus kuda hasil persilangan pejantan Thoroughbred dengan induk lokal Indonesia yang telah berumur $\geq 12$ tahun adalah $25,4 \pm 3,38$ hari dengan dua sampai tiga gelombang folikel. Rerata diameter folikel terbesar maksimum sebelum ovulasi adalah 4,2 $\pm 1,24 \mathrm{~cm}$ dengan kisaran 3,0 sampai dengan 5,8 cm. Tingkah laku estrus pada saat menjelang ovulasi ditandai dengan pencapaian skor maksimal pada nilai 3, yang dicirikan dengan lebih menunjukkan ketertarikan, mengangkat ekor, squatting, serta urinasi, dan pada nilai 4 yang dicirikan dengan ketertarikan yang kuat, menyodorkan pantat pada jantan, dan winked vulva, serta urinasi yang berkelanjutan.

\section{Daftar Pustaka}

Bergfelt, D. R., C. Meira, J. J. Fleury, P. D. Fleury, J. A. Dell'Aqua, G. P. Adams. 2007. Ovulation synchronization following commercial application of ultrasound-guided follicle ablation during the estrous cycle in mares. Theriogenology 68: 1183-1191.

Berliana, D. 2007. Analisis dan evaluasi genetik kuda pacu Indonesia. Tesis Sekolah Pasca Sarjana Institut Pertanian Bogor, Bogor.

Coleman, R. J. and D. Powell. 2004. Teasing Mares. Cooperative Extention Service. University of KentuckyCollege of Agriculture.

Donadeu, F. X. and O. J. Ginther. 2002. Changes in concentrations of follicular fluid factors during follicle selection in mares. J. Biol. Reprod. 66: 11111118.

Gastal, E. L., L. A Silva, M. O. Gastal and M. J. Evans. 2006. Effect of different doses of hCG on diameter of the preovulatory follicle and interval to ovulation in mares. Anim. Reprod. Sci. 94: 186-190.

Ginther, O. J. 1992. Reproductive Biology of The Mare: Basic and Applied Aspects. WI: Equiservices Publishing, Cross Plains.

Ginther, O. J., E. L. Gastal, M. O. Gastal, D. R. Bergfelt, A. R. Baerwald and R. A. Pierson. 2004. Comparative study of 
the dynamics of follicular waves in mares and women. Biol. Reprod. 71: 1195-1201.

Hafez, E. S. E. 2000. Reproduction in Farm Animals. $7^{\text {th }}$ edn. Lea and Febiger, Philadelphia.

Samper, J. C., H. Geertsema and P. Hearn. 1993. Rate of luteolysis, folliculogenesis and interval to ovulation of mares treated with a prostaglandin analogue on $\mathrm{d} 6$ or 10 of the estrous cycle. Proc. Am. Assoc. Equine Pract: 169-71.

Samper, J. C. 2008. Induction of estrus and ovulation: Why some mares respond and others do not. Theriogenology 70 : 445-447.

Steel, R. G. D. dan J. H. Torrie 1999. Prinsip dan Prosedur statistika. Edisi ke-2. Gramedia Pustaka Utama, Jakarta.

Waring, G. H. 2003. Horse Behavior. $2^{\text {nd }}$ edn. Noyes Publication William Andrew Publishing, New York.

Shirazi, A., F. Gharagozloo and H. Ghasemzadeh-Nava. 2004. Ultrasonic characteristics of preovulatory follicle and ovulation in caspian mares. J. Anim. Reprod. Sci. 80: 261-266. 